\title{
An Ashkenazi Jewish woman presenting with favism
}

\author{
F Lim, T Vulliamy, S H Abdalla
}

J Clin Pathol 2005;58:317-319. doi: 10.1136/icp.2004.017426

The case of a 44 year old Ashkenazi Jewish woman of Russian origin who presented with a typical clinical and haematological picture of favism is reported. There was initial difficulty in confirming glucose-6-phosphate dehydrogenase (G6PD) deficiency because the enzyme concentrations were normal at presentation, but later fell to a concentration compatible with heterozygosity for the Mediterranean type of G6PD deficiency. The diagnosis was also later confirmed by gene analysis. The reasons for the difficulties in the initial confirmation of the diagnosis and the normal G6PD enzyme activity at presentation are discussed.

G lucose-6-phosphate dehydrogenase (G6PD) deficiency is an inherited disease with a high prevalence in Africa, southern Europe, the Middle East, South East Asia, and Oceania and in descendants of migrants from these areas. G6PD is involved in the production of NADPH, which maintains glutathione, and consequently other proteins, in the reduced state when erythrocytes are subjected to an oxidant stress. Reduced concentrations of G6PD render red blood cells susceptible to haemolysis under conditions that occur when oxidant drugs are administered, when fava beans are ingested (favism), or during infection. ${ }^{1}$

\section{"Heterozygous females can also be affected in some circumstances, because of the existence of a population of deficient cells"}

Because G6PD deficiency is an X linked disorder, the main clinical manifestations are seen in hemizygous males. In areas where G6PD deficiency is prevalent, homozygous females will also be affected in the same way as hemizygous males. However, heterozygous females can also be affected in some circumstances, because of the existence of a population of deficient cells. In some cases, because of extremely skewed lyonisation, the population of deficient cells is much larger, and the total red cell enzyme concentrations may be similar to those in hemizygous males, leading to haemolysis on exposure to oxidant drugs or fava beans.

The difficulties in diagnosing G6PD deficiency in hemizygous males with the $\mathrm{A}^{-}$type of G6PD deficiency immediately after a haemolytic event is well recognised by most haematologists. This difficulty does not arise in males with the Mediterranean enzyme deficiency because reticulocytes do not have high enzyme concentrations. The situation in females heterozygous for the deficiency is less clear, and an extensive search in textbooks and on Medline failed to find a reference to enzyme concentrations in red blood cells in this situation.

Here, we report a female patient who was heterozygous for Mediterranean G6PD deficiency. She presented with favism and her enzyme concentrations were normal at presentation, causing a delay in making a definitive diagnosis.

\section{CASE REPORT}

A 44 year old woman presented to the accident and emergency department with a five day history of feeling tired and unwell, associated with bouts of vomiting. She also noticed that she had yellow sclerae and dark urine. She denied a history of foreign travel or the usage of herbal medications or illicit drugs. On further questioning, she recalled consuming two separate meals of frozen broad beans 48 hours and 24 hours before her symptoms began. She consumed an entire 1 pound packet of beans on those two occasions and in each case the beans were lightly boiled. There was no history of neonatal jaundice. There was no family history of jaundice or anaemia, and the only past medical history of note was that of two caesarean sections, the second involving a blood transfusion. On examination, she was clinically jaundiced with mild pitting oedema of the ankles. Her pulse was 100 beats/minute regular, with a blood pressure of 110/90 mm Hg. Oxygen saturation on room air was $100 \%$. Examination of the cardiovascular, respiratory, and abdominal systems was normal. An ultrasound scan of the abdomen was normal. Table 1 shows the results of blood tests performed on admission. The patient's blood film showed polychromasia with several polychromatic macrocytes and frequent irregularly contracted cells, suggestive of oxidant induced red blood cell damage. Haptoglobulins were absent from the serum on screening. While in hospital, the patient was transfused with one unit of blood and her haemoglobin $(\mathrm{Hb})$ rose to $81 \mathrm{~g} /$ litre. Her G6PD assay on admission was 7.2 U/g Hb (normal range, 4.6-13.5 U/g Hb). Because of the classic clinical history and blood film appearances the investigations were repeated four and eight weeks after presentation (table 2). Although her father had

Table 1 The patient's haematological and biochemical parameters at presentation

\begin{tabular}{|c|c|c|}
\hline Parameter & Result & $\begin{array}{l}\text { Laboratory reference } \\
\text { range }\end{array}$ \\
\hline Haemoglobin & $55 \mathrm{~g} / \mathrm{l}$ & $115-151 \mathrm{~g} / \mathrm{l}$ \\
\hline MCV & $105 \mathrm{fl}$ & $84-98 \mathrm{fl}$ \\
\hline Reticulocyte count & $133 \times 10^{9} / 1$ & $13-98 \times 10^{9} / 1$ \\
\hline Platelet count & $205 \times 10^{9} / 1$ & $147-39710^{9} / 1$ \\
\hline White cell count & $7.8 \times 10^{9} / 1$ & $5.1-11.4 \times 10^{9} / 1$ \\
\hline Monospot & Negative & \\
\hline G6PD assay & $7.2 \mathrm{U} / \mathrm{g} \mathrm{Hb}$ & $4.6-13.5 \mathrm{U} / \mathrm{g} \mathrm{Hb}$ \\
\hline Urine haemosiderin & Negative & \\
\hline Red cell folate & $597 \mu \mathrm{g} / \mathrm{l}$ & $215-650 \mu \mathrm{g} / \mathrm{l}$ \\
\hline Vitamin $B_{12}$ & $475 \mathrm{ng} / \mathrm{l}$ & $125-600 \mathrm{ng} / \mathrm{l}$ \\
\hline Bilirubin & $48 \mu \mathrm{mol} / \mathrm{l}$ & $<17 \mu \mathrm{mol} / \mathrm{l}$ \\
\hline $\mathrm{LDH}$ & $2197 \mathrm{U} / \mathrm{I}$ & $50-450 \mathrm{U} / \mathrm{I}$ \\
\hline $\mathrm{C}$ reactive protein & $16 \mathrm{mg} / \mathrm{l}$ & $<5 \mathrm{mg} / \mathrm{l}$ \\
\hline
\end{tabular}

Abbreviations: G6PD, glucose-6-phosphate dehydrogenase; $\mathrm{Hb}$, haemoglobin 
Table 2 Serial haematological parameters and G6PD values in the patient and in her father

\begin{tabular}{llll} 
Date & G6PD (U/g Hb) & Reticulocyte count & $\mathrm{Hb}$ \\
\hline $\begin{array}{l}\text { At presentation, } \\
\text { before transfusion }\end{array}$ & 7.2 & $133 \times 10^{9}$ & $55 \mathrm{~g} / \mathrm{l}$ \\
4 weeks later & 4.70 & $128 \times 10^{9}$ & $110 \mathrm{~g} / \mathrm{l}$ \\
8 weeks later & 2.50 & $24 \times 10^{9}$ & $153 \mathrm{~g} / \mathrm{l}$ \\
Father & 0.32 & $73 \times 10^{9}$ & $149 \mathrm{~g} / \mathrm{l}$ \\
\hline
\end{tabular}

G6PD, Glucose-6-phosphate dehydrogenase; $\mathrm{Hb}$, haemoglobin.

no history of haemolysis he was found to be G6PD deficient (table 2), whereas her mother was found to be normal. PCR amplification and Mbo II digestion of exon 6 of the G6PD gene showed that the patient is heterozygous for the $563 \mathrm{C}>\mathrm{T}$ mutation of G6PD Mediterranean. The patient has been counselled with regard to possible precipitating factors for haemolysis-for example, fava beans and drugs such as quinolones and sulfonamide antibiotics.

\section{DISCUSSION}

Steady state enzyme concentrations in G6PD deficiency are determined by the type of inherited defect. Thus, they are very low in the Mediterranean type of defect (less than 10\% of normal $)^{2}$ and are higher in the African $\mathrm{A}^{-}$type of deficiency (10-60\%). In addition, in the $\mathrm{A}^{-}$type of deficiency enzyme concentrations are much higher in reticulocytes than in aged red blood cells, with a fairly rapid decline in a few days, leading to a biphasic pattern in red cell enzyme concentrations after a haemolytic episode. ${ }^{34}$ The rise in enzyme concentrations caused by reticulocytosis to within the normal range in the $\mathrm{A}^{-}$defect has two practical consequences: (1) haemolysis is usually self limiting and less severe, and (2) the normal enzyme concentration renders the diagnosis of deficiency difficult to make in these patients during haemolysis. This is not thought to be the case in the Mediterranean type of deficiency, where enzyme concentrations are low even in reticulocytes, ${ }^{56}$ so that in this type of deficiency there is usually no difficulty in making the diagnosis during a haemolytic episode in male patients.

\section{"Our case is also a reminder that reliance on ethnic origin in the diagnosis of inherited red blood cell defects can be misleading"}

The situation in female patients is more complex. It is well documented that female patients heterozygous for G6PD deficiency have two cell populations-one with a normal enzyme content and one deficient in enzyme-and this is used as the basis for a cytochemical test. ${ }^{7}$ Therefore, the cell population deficient in enzyme would probably lyse when exposed to an oxidant challenge, leaving behind a population of cells with a normal enzyme content. This in turn will lead to an increased average enzyme concentration in the remaining cells. The increased enzyme concentration would be further augmented by compensatory reticulocytosis because of the high concentration of enzyme in the reticulocytes of the red cell population with normal enzyme.

Most individuals who are G6PD deficient remain clinically asymptomatic. However, they are at risk of developing acute haemolytic anaemia in response to three types of trigger, namely: drugs, infections, and broad (fava) beans. In most cases the haemolytic attack is self limiting. Depending on the number of red blood cells that have been destroyed, the haemoglobin concentration returns to normal in three to six weeks.
Take home messages

- An Ashkenazi Jewish woman of Russian origin presented with a typical clinical and haematological picture of favism, but there was initial difficulty in confirming glucose-6-phosphate dehydrogenase (G6PD) deficiency because enzyme concentrations were normal at presentation

- The enzyme later fell to a concentration compatible with heterozygosity for the Mediterranean type of G6PD deficiency, which was confirmed by gene analysis

- This can be explained by the fact that heterozygous female patients with G6PD deficiency have two cell populations - one with a normal enzyme content and one deficient in enzyme. The deficient cell population would probably lyse when exposed to an oxidant challenge, leaving behind cells with a normal enzyme content

Favism results from the presence in fava beans of two $\beta$ glycosides-vicine and convicine-which contain the pyramidines divicine and isouramil. These produce free radicals during auto-oxidation, leading to haemolysis in G6PD deficient subjects. The blood film shows polychromasia, anisocytosis, poikilocytosis, and "blister" cells-all features of acute oxidant induced haemolysis. G6PD deficient individuals do not develop favism every time they consume broad beans; the reasons for this are not clear. However, what is important is the quality and quantity of broad beans consumed. In our case, the beans were consumed in large amounts and were lightly boiled, and this may have a bearing on the occurrence of haemolysis.

At presentation, the enzyme assay in our case gave a misleading result-within the normal range. Subsequent enzyme assays showed decreasing enzyme concentrations.

Haemolysis and favism have been described in female patients heterozygous for the Mediterranean type of G6PD deficiency. ${ }^{8}$ However, after an extensive Medline search, we found no reports in the English language literature of difficulty in diagnosis, such as that described in hemizygous male patients with the $\mathrm{A}^{-}$type of deficiency. Therefore, we think that our case is an important documentation of this difficulty in diagnosis.

Our case is also a reminder that reliance on ethnic origin in the diagnosis of inherited red blood cell defects can be misleading. Although the Mediterranean type of G6PD deficiency is common in Sephardic Jews, who originate mainly from the Middle East and north Africa, it is not a common disease in Ashkenazi Jews (the ethnic group of our patient), who originate from central Europe and Russia.

\section{Authors' affiliations}

F Lim, Department of Haematology, St Mary's Hospital, Praed Street, London W2 INY, UK

T Vulliamy, S H Abdalla, Department of Haematology, Imperial College Faculty of Medicine, Hammersmith Campus and St Mary's Campus London W2 IPG, UK

The patient gave full consent for the details of this case to be published

Correspondence to: Dr S H Abdalla, Department of Haematology Imperial College Faculty of Medicine, St Mary's Campus, London W2 IPG, UK; s.abdalla@imperial.ac.uk

Accepted for publication 1 September 2004 


\section{REFERENCES}

1 Mehta A, Mason PJ, Vulliamy TJ. Glucose-6-phosphate dehydrogenase deficiency. Baillieres Best Pract Res Clin Haematol 2000;13:21-38.

2 Report of a WHO Scientific Group. Standardization of procedures for the study of glucose-6-phosphate dehydrogenase. World Health Organ Tech Rep Ser 1967;366:1-53

3 Beutler E. How do red cells age? Hypothesis and facts. Br J Haematol 1986;64:408-9.

4 Lakomek M, Shroter W, De Maeyer G, et al. On the diagnosis of erythrocyte enzyme deficiencies in the presence of high reticulocyte counts. $\mathrm{Br} J$ Haematol 1989;72:445-51.
5 De Flora A Morelli A, Benatti U Structural variants of human glucose 6 phosphate dehydrogenase (G6PD): role of intracellular decay in the expression of deficiency. Biomed Biochim Acta 1983;42:S247-52.

6 Piomelli S, Corash LM, Davenport D, et al. In vivo lability of glucose-6phosphate dehydrogenase in $\mathrm{GD}^{\mathrm{A}-}$ and $\mathrm{Gd}$ Mediterranean deficiency. J Clin Invest 1968;47:940-8.

7 Toenz O, Rossi F. Morphological demonstration of 2 red cell populations in human females heterozygous for glucose-6-phosphate deficiency. Nature 1964;9:606-7

8 Corchia C, Balata A, Meloni GF, et al. Favism in a female newborn infant whose mother ingested fava beans before delivery. J Pediatr 1995; 127:807-8. 